\title{
Low-dose Indonesian Aloe vera Increases Viability and Migration of the Fibroblast: An In Vitro Study
}

\author{
Januar Rizqi* (D), Akbar Satria Fitriawan (D) \\ Department of Nursing, Faculty of Health Sciences, Universitas Respati Yogyakarta, Yogyakarta 55282, Indonesia
}

\begin{abstract}
BACKGROUND: Important stages in wound healing involve homeostasis, inflammation, proliferation, and remodeling phases. Fibroblasts are essential factors in the healing pathway through the process of cell proliferation and migration. Aloe vera contains various active compounds used for anti-inflammatory, antimicrobial, immunomodulatory, anticancer, and wound healing.

AIM: This study aimed to evaluate the effect of A. vera on the viability and migration of fibroblast cells.

MATERIALS AND METHODS: Fibroblasts were cultured in a monolayer with Dulbecco's Modified Eagle Medium containing $10 \%$ fetal bovine serum, $1 \%$ pinstripe, and $0.5 \%$ fungizone. We use fresh $A$. vera leaves extracted with $95 \%$ ethanol. Cell viability will be evaluated using the MTT test and microscopic evaluation. Cell migration was tested using an in vitro wound scratch assay and analyzed with ImageJ software.

RESULTS: $A$. vera stimulated cell viability compared to control $(p<0.05)$. Administration of $A$. vera does not change shape and is not toxic to fibroblasts. $A$. vera stimulated cell migration at doses of $250,125,50$, and $5 \mu \mathrm{g} / \mathrm{mL}$ compared to control after $24 \mathrm{~h}$ of intervention. At $48 \mathrm{~h}$ incubation, migration doses of 250,50 , and $5 \mu \mathrm{g} / \mathrm{mL}$ were higher than control $(p<0.05)$.

CONCLUSIONS: $A$. vera extract may effectively wound healing by increasing viability and migration of fibroblast cells.
\end{abstract}

\section{Introduction}

The skin is a protection for the human body from infection and extrinsic trauma. Wounds can be described as a breakdown of the anatomic and functional integrity of the skin epithelial tissue [1]. The wound healing process is very complex, including physiological, cellular, and molecular events involving the homeostatic, inflammatory, proliferative, and remodeling to repair tissue damage [2]. The homeostatic phase begins after injury, platelets, and the blood coagulation cascade causes fibrin clotting to advance to the next step [3]. Neutrophils start to migrate to the wound bed, starting an inflammatory phase that acts as phagocytosis [4]. Macrophages contribute to the release of plateletderived growth factor and tumor growth factor (TGF- $\beta$ ), triggering the migration of fibroblast cells to the wound bed to initiate the proliferative phase [5].

The proliferative phase plays an essential role in the formation of granulation tissue and angiogenesis. Fibroblasts are the primary cells in the proliferative phase, producing extracellular cell matrix (ECM) such as collagen, proteoglycans, glycoproteins to replace fibrin clots, and accelerate wound healing [6]. Fibroblasts also produce matrix proteins such as vascular endothelial growth factor (VEGF), which play an essential role in angiogenesis [7]. The remodeling phase maintains a balance between ECM degradation and synthesis, regulated by matrix metalloproteinase (MMP) until complete healing is achieved [8].

Wound management aims to heal wounds with minimal pain, scarring, and shorten healing time. The latest treatment principle is to provide a moist environment for the damage using the proper dressing [9]. A moist wound environment will accelerate the proliferation and migration of fibroblast cells [10], [11]. In general, many dressings that have been used, such as silver and alginate, function to create a moist environment in the wound area and have antiinflammatory and antimicrobial effects [12]. However, this type of dressing requires a very high cost, and it is difficult for people in the area to obtain it [13]. Therefore, we need alternative natural ingredients that are readily available and more economical, such as Aloe vera.

$A$. vera is a valuable medicinal plant for wound healing and has biological activities such as antifungal, anti-inflammatory, immunomodulatory, and antibacterial effects [14], [15]. A. vera is non-toxic and does not affect the morphology of fibroblast cells [16], [17], has bioactive compounds such as acetylated mannans, polymannans, anthraquinone C-glycosides, anthrones, 
anthraquinones, and lectins which are therapeutically helpful [15]. Aloin in $A$. vera can induce increased expression of TGF- $\beta 1$, VEGF [18], and increase proliferation, migration of endothelial cells, and fibroblasts to accelerate wound healing [19].

Fibroblasts are the most abundant cells in connective tissue that plays an essential role in wound healing [20]. Mouse fibroblast cells have been used to model eukaryotic cells similar to human fibroblasts [21]. The purpose of this study was to explore the effect of local Indonesian $A$. vera on cell viability and migration, which was evaluated through the microculture tetrazolium test (MTT) test and wound scratch assay.

\section{Materials and Methods}

\section{extracts}

\section{Collection of plant materials and plant}

A. vera was obtained from the Self-help Agricultural and Rural Training Center (P4S) in Yogyakarta, Indonesia. Extracts were made using a method that has been modified by previous researchers [18]. $A$. vera leaves were washed and then dried in an oven at $60^{\circ} \mathrm{C}$. The dried leaves are then blended into a fine powder. $A$. vera extract preparation was macerated with $95 \%$ ethanol at room temperature for $24 \mathrm{~h}$, then filtered with Whatman paper no. 1. The extract was concentrated using a rotary evaporator, then freeze-dried at $-55^{\circ} \mathrm{C}$, then transferred to a bottle and stored at $-8^{\circ} \mathrm{C}$.

\section{To obtain a stock solution}

The ethanol extract of $A$. vera was dissolved with $1 \%$ dimethyl sulfoxide (DMSO; SIGMA®; St. Louis, $\mathrm{MO}$, USA). The stock solution was then diluted into a growth medium (Dulbecco's Modified Eagle Medium [DMEM]) to test the concentrations, namely, 500, 250, 125, and 50 and $5 \mu \mathrm{g} / \mathrm{mL}$. ALGISITE-M (Smith \& Nephew $\circledast$ ) was used as the control group. He made the Algisite-M® test by cutting the dressing in $1 \mathrm{~cm}^{2}$ size and then incubating it in $4 \mathrm{~mL}$ of growth media in an incubator at $37^{\circ} \mathrm{C}$ for $24 \mathrm{~h}$.

\section{Cell culture}

The NIH 3T3 cell line used in this study was obtained from the Pharmacology and Therapeutics Laboratory, Universitas Gadjah Mada, Indonesia. This research was conducted after obtaining approval from the research ethics committee of the Integrated Research and Testing Laboratory (LPPT), Universitas Gadjah Mada (code of ethical conduct: 00012/04/LPPT/ III/2020). Fibroblast cells were cultured and well cared for. Cells were cultured under standard conditions, with DMEM containing $10 \%$ fetal bovine serum (FBS, Sigma), $1 \%$ Pen-Strep, and $0.5 \%$ fungizone (GIBCO ${ }^{\circ}$, Grand Island, NY, USA) in an incubator in $5 \% \mathrm{CO}^{2}$ at $37^{\circ} \mathrm{C}$. The culture medium was changed 3 times a week. Trypsin $1 \%$ was used to separate fibroblast cells from culture wells.

\section{Fibroblast 3-(4,5-Dimethylthiazol-2-yl)-2,5-} diphenyl tetrazolium bromide (MTT) assays

NIH 3T3 cells, $1 \times 10^{4}$ were inserted into a 96-well microplate $(100 \mathrm{~L} /$ well $)$ for $24 \mathrm{~h}$. The media was replaced with the tested concentrations of $500,250,125,50$, and $5 \mu \mathrm{g} / \mathrm{mL}$, Algisite-M® as a control media, incubated again for 24 and $48 \mathrm{~h}$. Each media well was replaced with $10 \mathrm{~L}$ of MTT reagent and incubated at $37^{\circ} \mathrm{C}$ for 4-6 h. The MTT was then discarded, and the formazan crystal file dissolved in $100 \mathrm{~L}$ sodium dodecyl sulfate (SDS) was incubated at room temperature for $12 \mathrm{~h}$. Optical cell density was measured using an enzymelinked immunosorbent assay (ELISA) at a wavelength of $595 \mathrm{~nm}$. The effect of $A$. vera extract on cell viability was calculated by calculating the percentage of cell viability $=($ Absorbance Treatment-Absorbance Media $) /$ (Absorbance control cells-Absorbance Media) x 100\%.

\section{In vitro wound scratch assay}

The scratch assay was used to determine the migration rate of fibroblast cells. The fibroblast migration test was carried out by modifying the technique used by Liang [22]. $5 \times 10^{4} \mathrm{NIH} 3 \mathrm{~T} 3$ cells were placed in a 24-well microplate and incubated in complete media (DMEM, $10 \%$ FBS, $1 \%$ Pen-Strep, and $0.5 \%$ fungizone) at $37^{\circ} \mathrm{C}$ and $5 \%$ CO2. After $24 \mathrm{~h}$ of incubation, the wound was made by scraping the cells in the well using a 10-200 L sterile pipette tip. Cell wells were washed with PBS. Cells were incubated with $A$. vera extract with various concentrations $(500,250,125,50$, and $5 \mu \mathrm{g} / \mathrm{mL})$, DMEM media as a control group, and Algisite-M® as a positive control. The lacerations were photographed at 0 h using a camera Moticam 350, 10x in JPEG format. The next series of images was photographed after 24 and $48 \mathrm{~h}$ of incubation. Migration rates were analyzed using "ImageJ" software, comparing the percentage of covered area (24 and $48 \mathrm{~h}$ ) with the values obtained at $0 \mathrm{~h}$. This experiment was carried out in triplicate.

\section{Statistical Analysis}

The data were analyzed using SPSS 22 software for Windows. All data are analyzed using oneway ANOVA test. The results obtained were compared with the control group with the multiple comparison post hoc LSD test. Differences between groups were significant with $p<0.05$. 


\section{Results}

Fibroblasts 3-(4,5-dimethylthiazol-2-yl)-2,5diphenyltetrazolium bromide assay

The effect of multiple doses of $A$. vera on cell survival could be assessed by the viability of fibroblasts given short-term exposure of $24 \mathrm{~h}$ (Figure 1). Administration of large doses of $A$. vera to small doses gradually increases the viability of fibroblasts. The highest increase in viability was observed at a dose of $5 \mu \mathrm{g} / \mathrm{mL}$. All A. vera concentrations showed a statistically significant difference in increasing viability compared to the control group $(p<0.05)$.

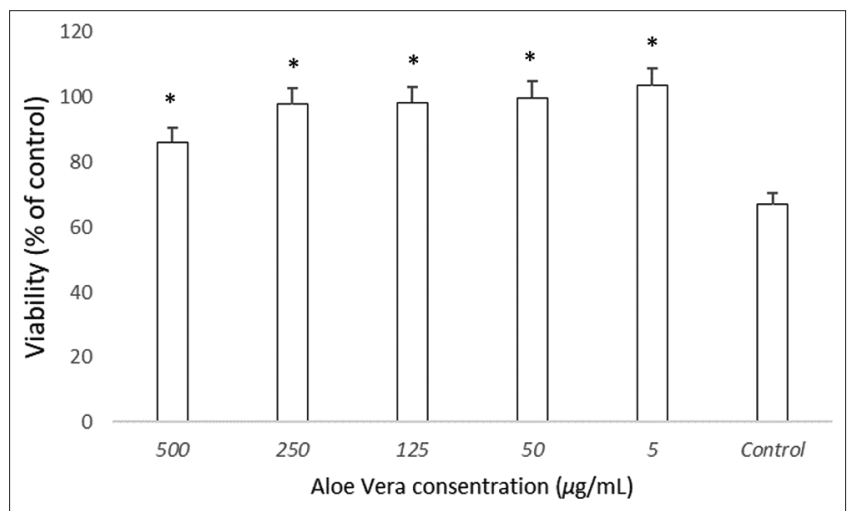

Figure 1: Cell viability after $24 \mathrm{~h}$ of treatment with various doses of Aloe vera. There was a difference in the viability of $A$. vera compared to the control $(p<0.05)$. Analysis of three trials $(n=3)$

\section{morphology}

\section{Effect of A. vera on fibroblast cell}

Healthy fibroblast cells can be observed by looking at the cell morphology. Normal fibroblast cells show an elongated, ovoid, and multipolar shape. Cell morphology changes did not occur after being given A. vera at $24 \mathrm{~h}$ (Figure 2). These results indicate that $A$. vera does not cause toxic effects on fibroblast cells.

\section{Effect of $A$. vera on fibroblast cell viability}

Cell viability at 24 and $48 \mathrm{~h}$ was measured to determine the effect of long-term exposure to $A$. vera on fibroblast cells. The administration of $A$. vera increased cell viability along with the administration of the smallest dose at $24 \mathrm{~h}$. There was a decrease in cell viability after $48 \mathrm{~h}$ of intervention (Figure 3 ). A dose of $5 \mu \mathrm{g} / \mathrm{mL}$ had the highest viability value compared to all $A$. vera groups and was significantly different $(p<0.05)$. The dose of $500 \mu \mathrm{g} / \mathrm{mL}$ showed the lowest proliferation value, statistically significant compared to the $5 \mu \mathrm{g} / \mathrm{mL}$ group and control cells.

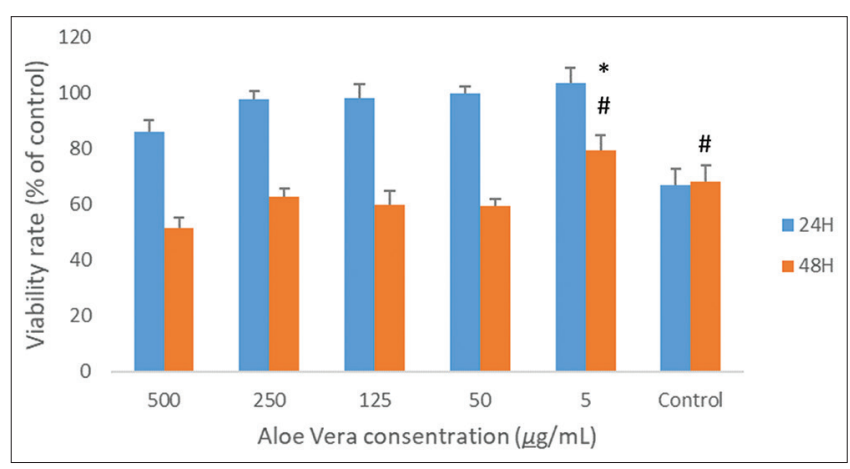

Figure 3: Viability of fibroblast cells at $24 h$ and $48 h$ after being given Aloe vera. ANOVA test in $24 h(p=0.000)$ and $48 h(p=0.009)$. $L S D$ post hoc; ${ }^{*}<0.05$ compared to all $A$. vera groups; \#< 0.05 compared to $A$. vera group at a dose of $5 \mu \mathrm{g} / \mathrm{mL}$

\section{Fibroblast in vitro wound scratch assay}

At the start of the in vitro wound scratch assay, there were no cells in the wound area (Figure 4). Migration of fibroblast cells increased after $24 \mathrm{~h}$ of $A$. vera treatment. Fibroblast cells begin to migrate to the center of the wound. Administration of $A$. vera in doses of $250,125,50$, and $5 \mu \mathrm{g} / \mathrm{mL}$ significantly increased migration after $24 \mathrm{~h}$ of treatment compared to the $500 \mu \mathrm{g} / \mathrm{mL}$ and control groups (Figure 5). Migration of fibroblast cells filled the wound area after $48 \mathrm{~h}$ of intervention. $A$. vera doses of $500,125,50$, and $5 \mu \mathrm{g} / \mathrm{mL}$ significantly increased migration after $48 \mathrm{~h}$ of

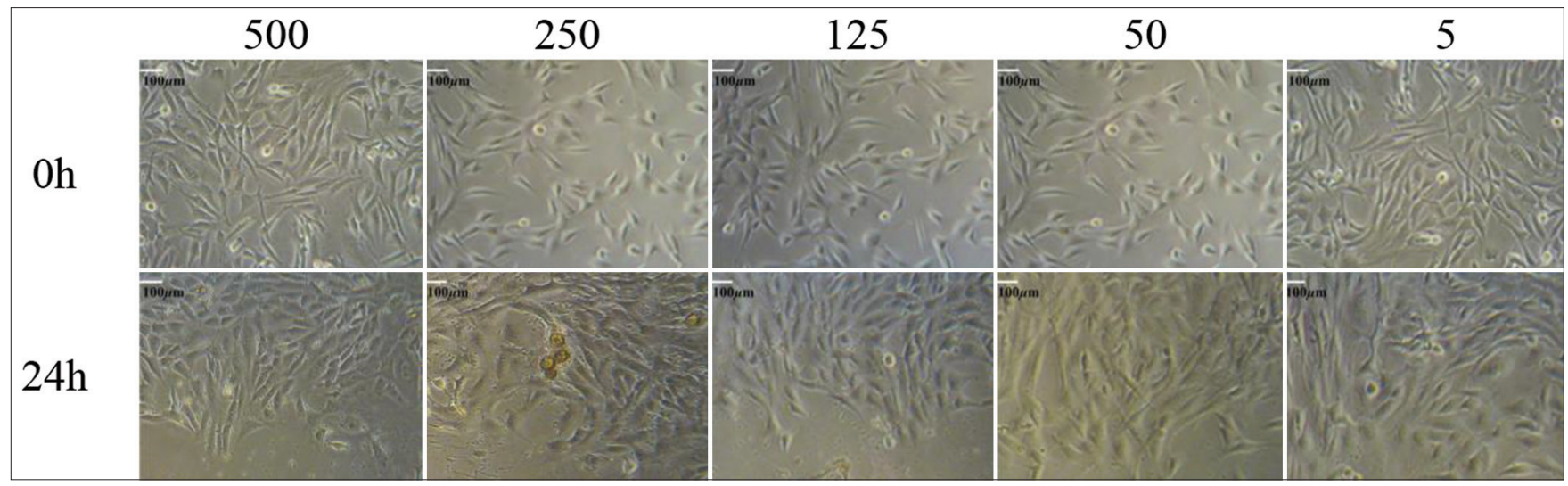

Figure 2: Morphology of fibroblast cells after being given Aloe vera. Images of fibroblasts were taken with 10x using a camera Moticam 350 microscope. Incubation of A. vera did not change cell morphology 
treatment compared to the $250 \mu \mathrm{g} / \mathrm{mL}$ dose group and the control group.

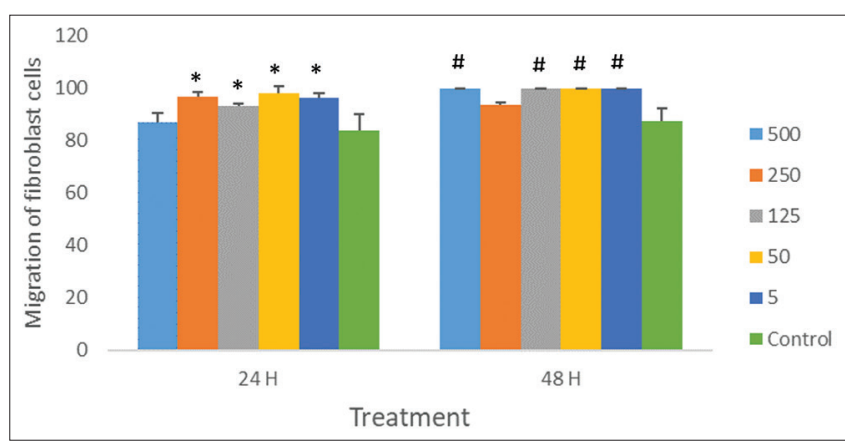

Figure 4: Migration of fibroblast cells given Aloe vera after 24 and $48 \mathrm{~h}$. ANOVA test in $24 h(p=0.000)$ and $48 h(p=0.000)$. LSD post hoc; $24 h$ ${ }^{*}(p<0.05)$ compared to the $500 \mu \mathrm{g} / \mathrm{mL}$ group and control cells; $48 \mathrm{~h}$ \# $(p<0.05)$ compared to the $250 \mu \mathrm{g} / \mathrm{mL}$ group and control cells

\section{Discussion}

The development of herbal medicine has attracted worldwide interest in recent years. Herbs are used because of their availability, lower costs, and lower side effects [23]. Some herbs have the potential to heal wounds without damaging healthy tissue, reduce infection, and increase wound healing time. We examined local Indonesian $A$. vera to determine the proliferation and migration of fibroblast cells. This shows that $A$. vera significantly increases cell viability and migration after the intervention.

Measurement of cell viability and proliferation is essential during the wound healing process. MTT test is a technique for estimating cell viability by measuring the metabolic activity of cells. Giving $A$. vera $24 \mathrm{~h}$ showed an increase in viability depending on the dose given. The rise in fibroblast cell viability was maximal at the lowest dose of $5 \mu \mathrm{g} / \mathrm{mL}$. After $48 \mathrm{~h}$, there was a decrease in cell viability. Different results were revealed by Soba et al. that $48 \mathrm{~h}$ of $A$. vera administration still increased viability. Samira et al. also reported an increase after $48 \mathrm{~h}$ of $A$. vera treatment, but it was not significantly different from the control group [18]. Other results can occur due to the use of $A$. vera from different types and locations.

Observation of cell morphology after being given $A$. vera did not appear to be abnormal. The morphology of healthy fibroblasts is elongated and multipolar. In their research, Saba et al. [17] showed that there were changes in fibroblasts that were flat and fan shaped, but this morphology was a characteristic of cells that had migrated. Fibroblasts will migrate to the wound site 48-72 h after injury and play an essential role in the wound healing [5].

We found that the administration of $A$. vera increased cell migration depending on the dose administered. $A$. vera group saw cell migration activity starting to move to the center of the wound after $24 \mathrm{~h}$ of intervention. Scratch wounds almost closed in the $50 \mu \mathrm{g} / \mathrm{mL}$ and $5 \mu \mathrm{g} / \mathrm{mL}$ concentration groups. At $48 \mathrm{~h}$, it was seen that some of the scratches had closed in some $A$. vera groups, except for the $250 \mu \mathrm{g} / \mathrm{mL}$ concentration group which had not closed the scratches compared to the control group. These results are also supported by the previous studies where $A$. vera can increase the proliferation and migration of rat dermal fibroblast cells [18]. Teplicy et al. [24] also confirmed that the benefits of $A$. vera could increase the proliferation and migration of keratinocyte and fibroblast cells in vitro.

A. vera is believed to have pharmacological benefits such as antioxidants, antimicrobials, and good immunity for wound healing [25]. A. vera has

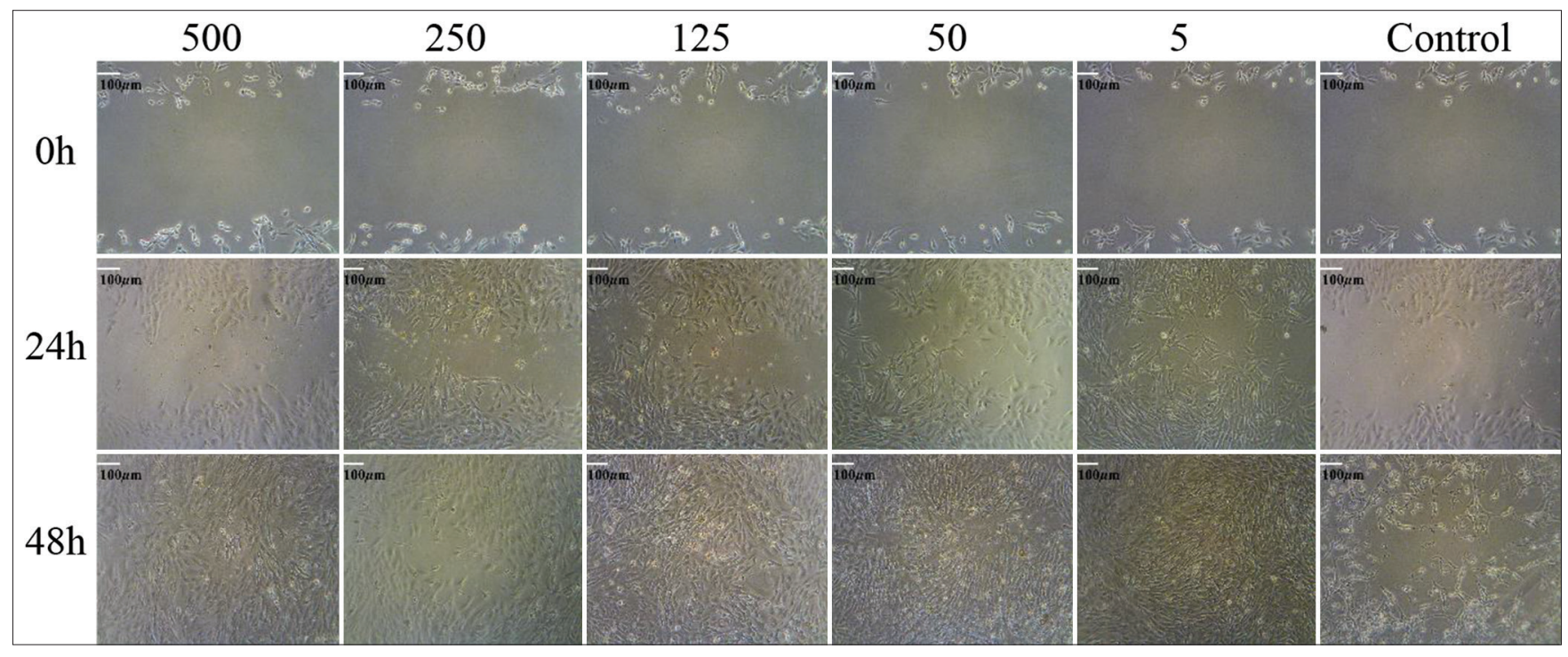

Figure 5: Migration of fibroblast cells starting from the beginning of the in vitro wound scratch assay and $24 \mathrm{~h}, 48 \mathrm{~h}$ after intervention with Aloe vera. The scale bar uses a $100 \mu \mathrm{m}$ magnification viewed with a $10 \times$ microscope 
components such as $5.5 \mathrm{kDa}$ glycoprotein, which increases growth factor TGF- $\beta 1$, and VEGF, one of the essential factors for tissue and organ growth [26], [27]. According to Wahedi and Hussain Mustatab et al., giving $A$. vera can shorten healing time by increasing angiogenesis through activation of SMAD and MAPK [28]. Angiogenesis plays a role in forming new blood vessels from the last blood vessels, which are regulated by signals from the surrounding serum and ECM. The polysaccharide content in $A$. vera can induce the expression of MMP-3 and metallopeptidase inhibitor-2 genes, which directly regulate wound healing activity in vivo [29].

In general, the effect of $A$. vera can increase cell proliferation and migration. Different findings occur due to plants from different locations with compositions and isolation techniques to extract $A$. vera [17]. According to Esua et al. [30], A. vera 's biological activity can be antagonistic and protagonist depending on veracylglucan $B$ and $C$. The content of veracylglucan $B$ in high amounts will cause delays in wound healing, while veracylglucan $\mathrm{C}$ in high amounts will result in poor wound healing positive [30]. Therefore, local Indonesian $A$. vera still needs to be explored in vivo and in vitro to accelerate wound healing.

\section{Conclusions}

The lowest dose of $A$. vera extract had a beneficial effect on wound healing. It increases the viability and migration of fibroblast cells. A. vera did not change the morphology of fibroblast cells.

\section{Ethical Approval}

This study was approved by the Integrated Research and Testing Laboratory (LPPT), Universitas Gadjah Mada, Indonesia, with the ethical expediency number 00012/04/LPPT/III/2020.

\section{References}

1. Sorg H, Tilkorn DJ, Hager S, Hauser J, Mirastschijski U. Skin wound healing: An update on the current knowledge and concepts. Eur Surg Res. 2017;58(1-2):81-94. https://doi. org/10.1159/000454919

PMid:27974711

2. Serra MB, Barroso WA, da Silva NN, Silva SD, Borges AC,
Abreu IC, et al. From inflammation to current and alternative therapies involved in wound healing. Int J Inflam. 2017;2017:3406215. https://doi.org/10.1155/2017/3406215 PMid:28811953

3. Jansen EE, Braun A, Jansen P, Hartmann M. Platelettherapeutics to improve tissue regeneration and wound healing-physiological background and methods of preparation. Biomedicines. 2021;9(8):869. https://doi.org/10.3390/ biomedicines 9080869

PMid:34440073

4. Wilgus TA, Roy S, McDaniel JC. Neutrophils and wound repair: Positive actions and negative reactions. Adv Wound Care (New Rochelle). 2013;2(7):379-88. https://doi.org/10.1089/ wound.2012.0383

PMid:24527354

5. Velnar T, Bailey T, Smrkolj V. The wound healing process: An overview of the cellular and molecular mechanisms. J Int Med Res. 2009;37(5):1528-42. https://doi. org/10.1177/147323000903700531 PMid:19930861

6. DeLisser HM. Modulators of endothelial cell filopodia. Cell Adh Migr. 2011;5(1):37-41. https://doi.org/10.4161/cam.5.1.13575 PMid:20935458

7. Olczyk P, Mencner $\measuredangle$, Komosinska-Vassev K. The role of the extracellular matrix components in cutaneous wound healing. Biomed Res Int. 2014;2014:747584. https://doi. org/10.1155/2014/747584

PMid:24772435

8. Soo C, Shaw WW, Zhang X, Longaker MT, Howard EW, Ting K. Differential expression of matrix metalloproteinases and their tissue-derived inhibitors in cutaneous wound repair. Plast Reconstr Surg. 2000;105(2):638-47. https://doi. org/10.1097/00006534-200002000-00024

PMid:10697171

9. Kuhlmann M, Wigger-Alberti W, Mackensen YV, Ebbinghaus M, Williams R, Krause-Kyora F, et al. Wound healing characteristics of a novel wound healing ointment in an abrasive wound model: A randomised, intra-individual clinical investigation. Wound Med. 2019;24(1):24-32.

10. Lordani TV, de Lara CE, Ferreira FB, de Souza Terron Monich M, da Silva CM, Lordani CR, et al. Therapeutic effects of medicinal plants on cutaneous wound healing in humans: A systematic review. Mediators Inflamm. 2018;2018:7354250. https://doi. org/10.1155/2018/7354250 PMid:29805312

11. Guo A, Song B, Reid B, Gu Y, Forrester JV, Jahoda CA, et al. Effects of physiological electric fields on migration of human dermal fibroblasts. J Invest Dermatol. 2010;130(9):2320-7. https://doi.org/10.1038/jid.2010.96

PMid:20410911

12. Raman SP, Keil C, Dieringer $P$, Hübner $C$, Bueno A, Gurikov $P$, et al. Alginate aerogels carrying calcium, zinc and silver cations for wound care: Fabrication and metal detection. J Supercrit Fluids. 2019;153:104545.

13. Payne WG, Posnett J, Alvarez O, Brown-Etris M, Jameson G Wolcott $R$, et al. A prospective, randomized clinical trial to assess the cost-effectiveness of a modern foam dressing versus a traditional saline gauze dressing in the treatment of Stage II pressure ulcers. Ostomy Wound Manage. 2009;55(2):50-5. PMid: 19246785

14. Shedoeva A, Leavesley D, Upton Z, Fan C. Wound healing and the use of medicinal plants. Evid Based Complement Alternat Med. 2019;2019:2684108.

PMid:31662773 
15. Sánchez M, González-Burgos E, Iglesias I, Gómez-Serranillos MP. Pharmacological update properties of aloe vera and its major active constituents. Molecules. 2020;25(6):1324. https:// doi.org/10.3390/molecules 25061324

\section{PMid:32183224}

16. Curto EM, Labelle A, Chandler HL. Aloe vera: An in vitro study of effects on corneal wound closure and collagenase activity. Vet Ophthalmol. 2014;17(6):403-10

17. Shafaie S, Andalib S, Shafaei H, Montaseri A, Tavakolizadeh M. Differential biological behavior of fibroblasts and endothelial cells under Aloe vera gel culturing. Int J Mol Cell Med. 2020;9(3):23446. https://doi.org/10.22088/IJMCM.BUMS.9.3.234 PMid:33274186

18. Negahdari S, Galehdari H, Kesmati M, Rezaie A, Shariati G. Wound healing activity of extracts and formulations of aloe vera, henna, adiantum capillus-veneris, and myrrh on mouse dermal fibroblast cells. Int J Prev Med. 2017;8(1):18. https://doi. org/10.4103/ijpvm.IJPVM_338_16 PMid:28382194

19. Hęś M, Dziedzic K, Górecka D, Jędrusek-Golińska A, Gujska E. Aloe vera (L.) Webb.: Natural sources of antioxidants-a review. Plant Foods Hum Nutr. 2019;74(3):255-65. https://doi. org/10.1007/s11130-019-00747-5 PMid:31209704

20. Li B, Wang JH. Fibroblasts and myofibroblasts in wound healing: Force generation and measurement. J Tissue Viability. 2011;20(4):108-20. https://doi.org/10.1016/j.jtv.2009.11.004 PMid:19995679

21. Li L, Fukunaga-Kalabis M, Herlyn M. The three-dimensional human skin reconstruct model: A tool to study normal skin and melanoma progression. J Vis Exp. 2011;(54):2937. https://doi. org/10.3791/2937

PMid:21847077

22. Liang CC, Park AY, Guan JL. In vitro scratch assay: A convenient and inexpensive method for analysis of cell migration in vitro. Nat Protoc. 2007;2(2):329-33. https://doi.org/10.1038/nprot.2007.30 PMid: 17406593

23. Pal SK, Shukla Y. Herbal medicine: Current status and the future. Asian Pac J Cancer Prev. 2003;4(4):281-8. PMid: 14728584

24. Teplicki E, Ma Q, Castillo DE, Zarei M, Hustad AP, Chen J, et al. The effects of aloe vera on wound healing in cell proliferation, migration, and viability. Wounds. 2018;30(9):263-8.

PMid:30256753

25. Radha MH, Laxmipriya NP. Evaluation of biological properties and clinical effectiveness of Aloe vera: A systematic review. J Tradit Complement Med. 2014;5(1):21-6. https://doi. org/10.1016/j.jtcme.2014.10.006

PMid:26151005

26. Hormozi M, Assaei R, Boroujeni MB. The effect of aloe vera on the expression of wound healing factors (TGF $\beta 1$ and bFGF) in mouse embryonic fibroblast cell: In vitro study. Biomed Pharmacother. 2017;88:610-6. https://doi.org/10.1016/j. biopha.2017.01.095

PMid:28142117

27. Choi SW, Son BW, Son YS, Park YI, Lee SK, Chung MH. The wound-healing effect of a glycoprotein fraction isolated from aloe vera. $\mathrm{Br} \mathrm{J}$ Dermatol. 2001;145(4):535-45. https://doi. org/10.1046/j.1365-2133.2001.04410.x

PMid:11703278

28. Wahedi HM, Jeong M, Chae JK, Do SG, Yoon H, Kim SY. Aloesin from Aloe vera accelerates skin wound healing by modulating MAPK/Rho and Smad signaling pathways in vitro and in vivo. Phytomedicine. 2017;28:19-26. https://doi.org/10.1016/j. phymed.2017.02.005 PMid:28478809

29. Tabandeh MR, Oryan A, Mohammadalipour A. Polysaccharides of Aloe vera induce MMP-3 and TIMP-2 gene expression during the skin wound repair of rat. Int J Biol Macromol. 2014;65:424-30. https://doi.org/10.1016/j.jijbiomac.2014.01.055 PMid:24491493

30. Esua MF, Rauwald JW. Novel bioactive maloyl glucans from Aloe vera gel: Isolation, structure elucidation and in vitro bioassays. Carbohydr Res. 2006;341(3):355-64. https://doi.org/10.1016/j. carres.2005.11.022

PMid:16343466 